https://doi.org/10.48009/2_iis_2014_89-97

Issues in Information Systems

Volume 15, Issue II, pp. 89-97, 2014

\title{
AN ASSESSMENT ON INFORMATION SYSTEMS CURRICULUM OBJECTIVES: ALUMNI PERSPECTIVES
}

\author{
Rosarito Sánchez-Morcilio, University of Puerto Rico, Río Piedras Campus, rosarito.sanchez@upr.edu \\ Francisco Quiles-Torres, University of Puerto Rico, Río Piedras Campus, francisco.quiles@upr.edu
}

\begin{abstract}
The Information Systems curricula must be revised regularly in order to address the needs of the students so they become effective Information Systems professionals. The results of this research showed a decrease in the Information Systems curricula effectiveness to adequately prepare alumni to compete as Information Systems professionals. This represents a challenge for Information Systems educators, which need to address such gaps in the Information Systems academic offerings to better prepare future Information Systems professionals. A model is presented to suggest which skills, according to alumni perceptions, are relevant to be mastered by Information Systems professionals. The model is the result of the comparison of two previous studies from 2011 and from 2013 with the use of frequency and proportion statistics. The model highlights the skills to be emphasized in the Information Systems curricula.
\end{abstract}

Keywords: Information Systems (IS) skills, Information Systems curriculum assessment, IS curriculum, Information Systems alumni, IS skills, IS skill set model.

\section{INTRODUCTION}

In today's continuous changing business environment, the skillset required by Information Systems (IS) practitioners needs to adapt to effectively compete and be successful in their careers (Reichgelt and Yaverbaum, [9]). A continuous revision of the IS program is critical to keep IT curricula up to the constant business models, business needs, and technology changes (Koohang, Riley, Smith \& Floyd, [6]). As a consequence, IS curriculum administrators must constantly revise the academic content based on the demands of the market. Many assessment processes are discussed in literature. The more successful an IS alumnus is, the more credibility in the IS field is perceived by the entities being served. To thrive for excellence, an IS curriculum must constantly be reassessed to assertively define its path. An IS curriculum can be assessed by its constituents, who are students, alumni, faculty, and other people being served by it (Koohang, et al. [6]). IS alumni are the best constituents for IS curriculum because they are familiar with its offerings and as practitioners in the IS field know the skills required to be successful in the business environment (Grant, Hackney, and Edgar, [5]). As Koohang, et al. [6] and the American Board of Engineering and Technology (ABET, [2]) - Computing Accreditation Commision (CAC) explained, an alignment is needed between the mission and vision of IS curriculum, its university and the objectives. In addition, ABET [2] establishes the objectives are broad statements that describe what graduates are expected to attain within few years of graduation. Those objectives are based on the needs of the program's constituencies and should be the educational purpose of the IS curriculum. Each objecive has a set of skills or outcomes associated to it. Outcomes are described in detail in the ABET [2] Criteria.

The purpose of the research was to find out the skills that need to be highlight in the IS curriculum according to the IS alumni accomplishment perceptions. This research compared the results of two previous studies performed on the years 2011 and 2013 to create a model with the skills that need to be emphasized in the IS curriculum for its effectiveness and continious improvement. The IS curriculum objectives assessed in this research were developed by Ramos-Torres [8]. Accomplishments referred to the premises, which define the value assigned by the alumnus to the objective. Associated to each objective's career and professional accomplishments, certain skills are needed to be mastered by alumni in their respective work environment. Each objective has one or two skills associated to it. The program's objectives and the respective skills required to achieve them are shown in Table 1. The table also shows the name of the variable used for this research. 
Table 1: Program's objectives, accomplishments, the name of the variable, and required skills

\begin{tabular}{|c|c|c|c|}
\hline $\begin{array}{l}\text { IS Program's } \\
\text { Objectives }\end{array}$ & $\begin{array}{l}\text { Career and Professional Accomplishments } \\
\text { (Ramos-Torres [8]). These items used in the } \\
\text { questionnaire. }\end{array}$ & $\begin{array}{l}\text { Name of the vari- } \\
\text { able }\end{array}$ & Skills \\
\hline \multirow{2}{*}{ Objective 1} & $\begin{array}{l}\text { 1- I have implemented information systems in an } \\
\text { organization. }\end{array}$ & ActiveParticipate & $\begin{array}{l}\text {-Implement or put a prototype, at } \\
\text { an early stage model, Infor- } \\
\text { mation System in place. }\end{array}$ \\
\hline & $\begin{array}{l}\text { 2- I have managed the development of infor- } \\
\text { mation systems in an organization. }\end{array}$ & ManageDev & $\begin{array}{l}\text {-Management of the develop a } \\
\text { prototype of an Information } \\
\text { Systems. }\end{array}$ \\
\hline \multirow{2}{*}{ Objective 2} & $\begin{array}{l}\text { 3- I have applied technological skills in the solu- } \\
\text { tion of problems related to information systems } \\
\text { in organizations. }\end{array}$ & ApplyTec & -Use technology effectively. \\
\hline & $\begin{array}{l}\text { 4- I have applied analytical and critical thinking } \\
\text { skills in the solution of problems related to in- } \\
\text { formation systems in organizations. }\end{array}$ & AnalyticCrit & $\begin{array}{l}\text {-Select the appropriate solution } \\
\text { to an issue arise from the Infor- } \\
\text { mation Systems. }\end{array}$ \\
\hline Objective 3 & $\begin{array}{l}\text { 5- I take into consideration the context in which } \\
\text { information systems operate (organizational cul- } \\
\text { ture, functional areas, industry regulations, etc.), } \\
\text { when implementing and managing these sys- } \\
\text { tems. }\end{array}$ & ContextSyst & $\begin{array}{l}\text {-Know the environment which } \\
\text { the Information Systems serves. }\end{array}$ \\
\hline Objective 4 & $\begin{array}{l}\text { 6- I maintain my professional expertise by up- } \\
\text { dating my knowledge in technology and infor- } \\
\text { mation systems. }\end{array}$ & LifeLong & $\begin{array}{l}\text {-Demonstrate to learn inde- } \\
\text { pendently in Information Sys- } \\
\text { tems topics to keep updated in } \\
\text { the IS field. }\end{array}$ \\
\hline \multirow{2}{*}{ Objective 5} & $\begin{array}{l}\text { 7- I perform my functions showing respect and } \\
\text { appreciation for ethical values and interpersonal } \\
\text { relationships. }\end{array}$ & EthicalIntPer & $\begin{array}{l}\text {-Demonstrate ethical values and } \\
\text { interpersonal skills. }\end{array}$ \\
\hline & $\begin{array}{l}\text { 8- I perform my functions emphasizing commu- } \\
\text { nication and teamwork. }\end{array}$ & CommTeam & $\begin{array}{l}\text {-Show effective communication } \\
\text { skills and work in teams effi- } \\
\text { ciently. }\end{array}$ \\
\hline
\end{tabular}

Since the programs objectives presented in Table 1 are both high level and very broad, another table to map each IS program objective with each outcome along with IS course is also available. Table 2 shows a mapping between each objective with each IS course where that objective is developed and emphasized. This table is useful to identify which courses need to be improved after analyzing the program's objective assessment results. 


\begin{tabular}{|c|c|c|}
\hline $\begin{array}{l}\text { IS Program's } \\
\text { Objectives }\end{array}$ & $\begin{array}{c}\text { IS program } \\
\text { course codes } \\
\text { (Ramos- } \\
\text { Torres [8]) }\end{array}$ & $\begin{array}{l}\text { IS program course titles } \\
\text { (Ramos-Torres [8]) }\end{array}$ \\
\hline $\begin{array}{c}\text { Objective } \\
1\end{array}$ & $\begin{array}{l}\text { CIS } 4025 \\
\text { CIS } 4015 \\
\text { CIS } 4266 \\
\text { CIS } 4405 \\
\text { CIS } 4278 \\
\end{array}$ & $\begin{array}{l}\text { Systems Analysis and Logical Design } \\
\text { Physical Design and Systems Implementation Using DBMS } \\
\text { Physical Design and Systems Implementation Using Emerging Tools } \\
\text { Design and Implementation of Electronic Business } \\
\text { Project Management and Administrative aspects of IS }\end{array}$ \\
\hline $\begin{array}{c}\text { Objective } \\
2\end{array}$ & $\begin{array}{l}\text { CIS } 3245 \\
\text { CIS } 3255 \\
\text { CIS } 4266 \\
\text { CIS } 4405 \\
\text { CIS XXX2 } \\
\text { CIS } 4015 \\
\text { CIS } 4286 \\
\text { CIS } 4285\end{array}$ & $\begin{array}{l}\text { Technological Infrastructure for Information Systems } \\
\text { Applications Programming } \\
\text { Physical Design and Systems Implementation Using Emerging Tools } \\
\text { Design and Implementation of Electronic Business } \\
\text { Decision Support Systems } \\
\text { Physical Design and Systems Implementation Using DBMS } \\
\text { Local Area Data Communication Networks } \\
\text { Wide Area Data Communication Networks }\end{array}$ \\
\hline $\begin{array}{c}\text { Objective } \\
3\end{array}$ & $\begin{array}{l}\text { CIS } 4015 \\
\text { CIS } 4278 \\
\text { CIS } 4266 \\
\text { CIS } 4405 \\
\text { CIS } 4465 \\
\text { CIS } 4275\end{array}$ & $\begin{array}{l}\text { Physical Design and Systems Implementation Using DBMS } \\
\text { Project Management and Administrative Aspects of IS } \\
\text { Physical Design and Systems Implementation Using Emerging Tools } \\
\text { Design and Implementation of Electronic Business } \\
\text { Seminar on Legal Aspects of Information Systems } \\
\text { Control and Security of Information Systems }\end{array}$ \\
\hline $\begin{array}{c}\text { Objective } \\
4\end{array}$ & CIS 4278 & Project Management and Administrative Aspects of IS \\
\hline $\begin{array}{c}\text { Objective } \\
5\end{array}$ & $\begin{array}{l}\text { CIS } 4275 \\
\text { CIS } 4465 \\
\text { CIS } 4998 \\
\text { CIS } 3245 \\
\text { CIS } 4278 \\
\text { CIS } 4025\end{array}$ & $\begin{array}{l}\text { Control and Security of Information Systems } \\
\text { Seminar on Legal Aspects of Information Systems } \\
\text { Cooperative Education Experience } \\
\text { Technological Infrastructure for Information Systems } \\
\text { Project Management and Administrative Aspects of IS } \\
\text { Systems Analysis and Logical Design }\end{array}$ \\
\hline
\end{tabular}

\section{LITERATURE REVIEW}

The program's objectives, as ABET [2] defines, are alumni IS professional accomplishments three years after graduation. The program's objectives assessment is an important activity to find if the IS curriculum is meeting the expectancies of its constituents. Constituents, according to ABET [2], all people who are related the IS curriculum such as students, alumni, employers, as well as college professors. Koohang, et al. [6] described the relevancy of the objectives in a IS program, especially if that program aims to comply with prestigious accreditation agencies, such as ABET [2]. The authors established that program's objectives must be measurable in order to be assessed. The program's objective assessment is key for the IS curriculum continuous improvement. Having a clear set of objectives makes the assessment process effective. The authors also mentioned that a set of objectives ensures the quality standards of the IS curriculum. Once objectives are established, the competencies can be elaborated accordingly. Each competency, or as ABET [2] named outcomes, is related to the IS curriculum courses.

The right selection of courses depends on the competencies, which are related to the objectives. The program's objectives are the IS curriculum professional goals to be achieved by alumni. Those objectives must be established according to the constituents' demands (ABET, [2]). Constituents are ideal to help determine the program' objectives since they are exposed to the IS field and know the actual business demands. Amadi, \& Born [3] explained IS curriculum program's objectives must constantly be revised to respond to the technological advances and its associated impact on business. The local business communities where the IS curriculum serves are fundamental to support in the program's objective evaluation. Constant integration between IS educators and the local businesses is important to address the program's objectives possible issues in responding to their needs. The Amadi, \& Born [3] study also described the latency period, which is the time difference between the realization and demand of a new skill and the implementation of curricular changes to address the new skill demands. The latency period includes 


\section{Issues in Information Systems \\ Volume 15, Issue II, pp. 89-97, 2014}

the realization and demand of a new program's objective, which is considered a skill or a knowledge need, and how that change is adopted into a new IS curriculum. A new skill may require the revision existing courses or the creation of new ones. The time frame will vary among the different college institutions. They recommended the establishment of best practices for effective curricular changes and implementation based on the connection and communication between academia and local business representatives.

Some authors defined the program's objectives as the skills to be emphasized in the IS curriculum or as skill gaps. Outlay, \& Krishnan [7] study is an example. They proposed to find the skill gaps for IS workers in the field of IS compliance and how IS curricula can meet those needs. Legislations can affect IS practice in many ways, especially in the health and payment scenarios. It is important for IS professionals to take into account the applicable laws when implementing an IS system.

The program's objective assessment can be done considering the opinion of employers. Aasheim, Shropshire, Lixin, $\&$ Kadlec [1] focused on the assessment of entry-level skills from the Information Technology (IT) industry leaders' view. Their study is important as it considered Information Technology manager opinions, who lead the industry. They used interviews as the methodology for their study. Based on their finding, they recommended that personal and interpersonal skills are most important for the IT managers. As for the technical skills, they recommended to give emphasis on operating systems, security, hardware, networking, and database. Thatcher, Dinger, \& George [10] also focused their study in the entry-level skills. The essence of their finding was, despite of the fact that the apparent trend toward soft skills, employers seems to prioritize technical skills over interpersonal skills. Their methodology was through interviews as well. IT employers are one of the main constituents for an IS program.

Some of the studies reviewed focused on which program's objectives or skills must be emphasized. Both the Aasheim, et al. [1] and the Thatcher, Dinger, \& George [10] studies explained effective communication and teamwork, as well as the appreciation for ethical values are relevant to the IT field and must be emphasized in the IS curriculum. Communication, teamwork, and ethics are known as the social component of the set of skills required by IT professional. In addition, they recommended IT educators to refine the work in team projects and to enrich extracurricular activities. Projects to be taught to students can be greatly improved by following the guidelines of the Project Management Institute (PMI). Other activities to improve the IS programs are internships, which help in developing contacts who can lead to full time employment after graduation. Another great study about which program's objectives or skills to be emphasized in the IS curricula, is the Topi, Valacich, Wright, Kaiser, Nunamaker Jr, Sipior, \& De Vreeda [11] study. The study focused on developing a balance skill set for IS curricula, within and outside of business schools. The authors did not mentioned which IT skills to be emphasized, but it clearly display a list of courses that can make any IS curricula to meet the demands of today's business environment. In fact, the guidelines Topi et al. [11] presented are extremely useful for the IS curricula assessment.

The IS program's objectives can be assessed from different perspectives. The program's objective assessment can be conducted by considering the opinion of business leaders, who can be employers or alumni. The Aasheim, et al. [1] and the Thatcher, Dinger, \& George [10] studies considered employers for entry-level positions as the main contributors for the program's objective assessment. In contrast, Grant, Hackney, and Edgar, [5] study described IS alumni to be the best constituents for the program's objective assessment since they are already familiar with IS curriculum offerings and as practitioners in the IS field know the skills required to be successful in the business environment. For the purpose of the research presented in this study, alumni was chosen to assess the program's objectives as they are considered not only graduates of the IS curriculum, but also business leaders in the IS field.

\section{Main contribution of the paper}

The revelancy of this research is to show a way to conduct IS curriculum program's objective assessment, which supports the continuous improvement of the IS program. The assessment consists in identifying which skills need to be emphasized in the IS curriculum. Such assessement considered alumni opinions and experiences as they have a clear knowledge of the IS program. The research goal was to compare the results of 2011 and 2013 studies among IS alumni of the important skills, which are required to be emphasized in the IS program in order for its graduates to effectively work on today's environment. Its results were used to develop a model, which can be used to improve IS curricula. The main hypothesis for this study are:

Null hypothesis:

The proportions of the accomplishments of the 2011 study and the 2013 study are positive or equal. 
Alternate hypothesis:

The proportions of the accomplishments of the 2011 study and the 2013 study are negative.

\section{METHODOLOGY}

For this research, data was collected using the same instrument (questionnaire) in two different years: 2011 and 2013. Participants in both of the previous studies (2011 and 2013) were IS alumni who graduated from the IS curriculum being assessed. The criteria for inclusion into the survey was that participants must have graduated from the IS curriculum being assessed. To comply with the criteria of inclusion, an invitation to complete the survey was only sent to those who have graduated from the program.

The selection of participants for the sample in both of the previous studies was done randomly based on alumni population. Simple random sampling was used for both studies. A list of alumni and their email addresses were collected from the University system, which was used to invite them to participate in the study. Alumni, who were invited to participate in the studies graduated from College of Business Administration, majoring from the IS program. The university is located in a Caribbean metropolitan area. The IS program is accredited by ABET and the College of Business Administration is accredited by the Association to Advance Collegiate Schools of Business (AACSB). A description of the particularities of both studies used for this research is next.

Alumni who graduated from the year 2005 to 2011 were sent an invitation letter to participate in the survey via electronic mail. The letter encouraged alumni, not only to fill out the questionnaire, but also to share it with other alumni who may be interested.

A total of 131 survey forms were sent, with a response rate of $31 \%(40 / 131)$. The questionnaire was available on line for the period of January to May 2011. The participants answered all of the questions. Alumni who graduated from the year 2005 to 2013 were invited. A total of 149 survey forms were sent, with a response rate of $13 \%$ (20/149). The questionnaire was available on line for the period of January to May 2013. The participants answered all of the questions.

The survey instrument consisted of a questionnaire created and validated by the IS Faculty from the same University where alumni graduated. The same instrument was used on both studies and administered online using a subscription from Formstack.com. A total of eight variables were used to measure the accomplishments. A Likert-scale was used to measure how strongly the participant felt about it. The scale consisted of "Very frequently" (VF), "Frequently" (F), "Sometimes" (S), and "Never" (N).

Cronbach's alpha was used to measure the internal consistency reliability (Gliem, \& Gliem, [4], UCLA [12]). Alphas for the 2011 and 2013 studies were .9900 and .9958 , respectively. Since both alphas exceeded the .7 threshold, the survey instrument used in both studies were considered reliable.

The $\mathrm{R}$ code statistical software was used to determine the difference in proportions from both studies, with a $95 \%$ confidence. The lower and the upper bound suggested changes in the proportions. A negative result implied a decrease in the level of the accomplishment achievement, leading to reject the main study null hypothesis.

Demographics for the 2011 study:

\section{FINDINGS}

- Bachelor major: Most alumni (100\%) graduated from the IS program. None of the participants graduated from IS program in combination with another major.

- Graduation year: Most alumni (35\%) graduated between 3 to 5 years ago. A $28 \%$ of the participants reported to be graduated more than 10 years ago. A $25 \%$ of participants graduated 2 years ago or less. The least $(12 \%)$ graduated 2 years ago or less.

- Current job position: Most alumni (35\%) occupied a position not mentioned in the list of options in the questionnaire. A $33 \%$ of alumni reported to be IS consultants. A $13 \%$ occupied a technical position. A $13 \%$ were managers in non-IS areas. The least (6\%) occupied a managerial position in the IS area of a company.

- Area of service: A $23 \%$ of the participants worked for banking and $23 \%$ worked in the area of IS products 


\section{Issues in Information Systems \\ Volume 15, Issue II, pp. 89-97, 2014}

and services. A $15 \%$ worked for education. A $13 \%$ of participants worked in accounting services. The rest $(26 \%)$ worked spread among government, healthcare, insurance, retailing, and other areas not specified.

- Size of the company: Most alumni (68\%) worked in companies of more than 100 employees. A $13 \%$ worked in a company with 1 to 10 employees. Another 13\% worked in a company from 51 to 100 employees. The rest $(6 \%)$ worked in companies with 11 to 50 employees.

- Location: Most alumni (68\%) worked in Puerto Rico. A $20 \%$ of alumni worked in the continental USA. The rest (13\%) worked in a foreign country.

Similar demographics are found in both studies. Demographics for the 2013 study:

- Bachelor major: Most alumni (90\%) graduated from the IS program. The rest $(10 \%)$ graduated either from the IS program combined with accounting or IS program combined with other discipline.

- Graduation year: Most alumni (35\%) graduated between 6 years to 10 years. A $25 \%$ of alumni graduated more than 10 years ago. Another $25 \%$ graduated 2 years ago or less. The least (15\%) graduated between 3 to 5 years ago.

- Current job position: Most alumni (35\%) occupied a technical position in the IS area. A $25 \%$ occupied a managerial position in the IS area. The rest ( $40 \%$ reported to be spread among IS consultants, IT audit managers, IT sales, IT government manager, and managers in non-IS areas.

- Area of service: Most participants (30\%) worked for government agencies, $20 \%$ in banking and another $20 \%$ in retailing of IS services and products. A $10 \%$ worked in the area of accounting services. The rest $(20 \%)$ of them reported to be spread among working in areas such as accounting services, education, hospitality, and insurance.

- Size of the company: Most alumni (80\%) worked in companies of 100 employees. The least $(20 \%)$ worked in companies with less than 100 employees.

- Location: Most alumni (75\%) worked in Puerto Rico. The rest (25\%) worked in the continental USA. None of them worked in foreign countries.

Descriptive statistics for the 2011 and 2013 studies are presented in Table 3.

Table 3: Descriptive statistics for both studies

\begin{tabular}{|l|c|c|c|c|c|c|}
\hline & \multicolumn{2}{|c|}{$\begin{array}{c}\text { Results for the 2011 study } \\
\text { (n=40) }\end{array}$} & \multicolumn{2}{c|}{$\begin{array}{c}\text { Results for the 2013 study } \\
(\mathbf{n = 2 0})\end{array}$} \\
\hline $\begin{array}{c}\text { Name of the } \\
\text { variables to } \\
\text { measure the } \\
\text { objective }\end{array}$ & Average & $\begin{array}{c}\text { Standard } \\
\text { Deviation }\end{array}$ & Median & Average & $\begin{array}{c}\text { Standard } \\
\text { Deviation }\end{array}$ & Median \\
\hline ActiveParticipate & .48 & .51 & 0.00 & .70 & .45 & 1.00 \\
\hline ManageDev & .38 & .49 & 0.00 & .65 & .46 & 1.00 \\
\hline ApplyTech & .80 & .41 & 1.00 & .90 & .36 & 1.00 \\
\hline AnalyticCrit & .85 & .36 & 1.00 & .95 & .33 & 1.00 \\
\hline ContextSyst & .88 & .33 & 1.00 & .90 & .36 & 1.00 \\
\hline LifeLong & .88 & .33 & 1.00 & .85 & .39 & 1.00 \\
\hline EthicalIntPer & 1.00 & 0.00 & 1.00 & 1.00 & .28 & 1.00 \\
\hline CommTeam & 1.00 & 0.00 & 1.00 & .95 & .33 & 1.00 \\
\hline
\end{tabular}

The frequency distribution for the variables of both studies is presented in Figure 1. 


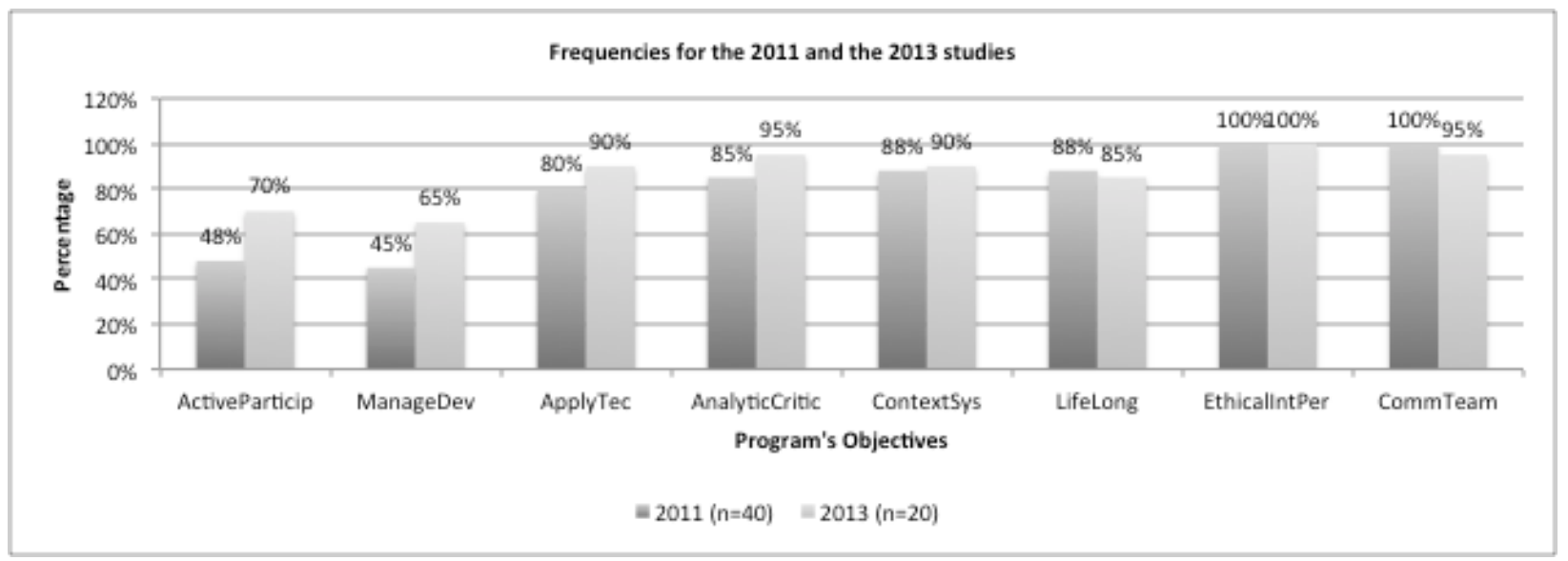

Figure 1: Frequencies for the 2011 and the 2013 studies

Table 4 presents the proportion comparison between the 2011 and 2013 studies. The table presents the name of the variables, the increase or decrease when comparing proportions, the number of success for the 2011 study with a sample size of 20, the number of success for the 2013 study with a sample size of 40 , the lower bound, the upper bound, and the last column shows if the null hypothesis is accepted or rejected.

Table 4: Proportions and Null Hypothesis analysis with a 95\% confidence interval

\begin{tabular}{|r|c|c|c|c|c|c|}
\hline $\begin{array}{c}\text { Name of the varia- } \\
\text { ble }\end{array}$ & $\begin{array}{c}\text { In- } \\
\text { crease/De } \\
\text { crease }\end{array}$ & $\begin{array}{c}\mathbf{2 0 1 1} \\
\text { Study, } \\
\text { where } \\
\mathbf{n 2 = 4 0}\end{array}$ & $\begin{array}{c}\mathbf{2 0 1 3} \\
\text { Study, } \\
\text { where } \\
\mathbf{n 1 = 2 0}\end{array}$ & $\begin{array}{c}\text { Lower Bound } \\
\text { (lb) }\end{array}$ & $\begin{array}{c}\text { Upper Bound } \\
\text { (ub) }\end{array}$ & $\begin{array}{c}\text { Null Hy- } \\
\text { pothesis }\end{array}$ \\
\hline ActiveParticipate & decrease & 19 & 14 & $-4.203 E-02$ & 0.4920339 & rejected \\
\hline ManageDev & increase & 15 & 13 & 0.007217941 & 0.5427821 & accepted \\
\hline ApplyTec & decrease & 32 & 18 & -0.100038 & 0.300038 & rejected \\
\hline AnalyticCrit & decrease & 34 & 19 & -0.07231157 & 0.2723116 & rejected \\
\hline ContextSyst & decrease & 35 & 18 & -0.1473116 & 0.1973116 & rejected \\
\hline LifeLong & decrease & 35 & 17 & -0.2074627 & 0.1574627 & rejected \\
\hline EthicalIntPer & $\begin{array}{c}\text { no differ- } \\
\text { ence }\end{array}$ & 40 & 20 & 0 & 0 & accepted \\
\hline CommTeam & decrease & 40 & 19 & -0.1187153 & 0.0187153 & rejected \\
\hline
\end{tabular}

\section{DISCUSSION}

The findings of this research are analyzed by using two statistical measures: frequencies (Figure 1) and proportions (Table 4). Based on the frequencies, from the 2011 to the 2013 study, all IS skills improved, except for Life long learning (LifeLong) and Communications and Teamwork (CommTeam), which showed a small reduction. However, based on the proportions, all IS skills decreased, except for Management and development an IS in an organization (ManageDev), which increased, and Ethical values and interpersonal relationships (EthicalIntPer), which remained the same. The main null hypothesis (the proportions of the accomplishments of the 2011 study and the 2013 study are positive or equal) is rejected according to these results.

By comparing the findings from both, the frequencies and the proportions statistics, they reflected contradictory results, except for Management and development an IS in an organization (ManageDev), which reflected an increase, Ethical values and interpersonal relationships (EthicalIntPer), which remained the same, and Communication and teamwork skills (CommTeam), which reflected a decrease. 


\section{Issues in Information Systems \\ Volume 15, Issue II, pp. 89-97, 2014}

Due to the fact that proportions statistics are more reliable than frequencies alone, the proportion results were used to develop the Skill Set of IS curricula model presented in Figure 2. This model suggests IS curricula must emphasize all IS skills, except for the Management as well as Ethical and interpersonal skills, which are already well addressed (those two skills are highlighted in the figure).

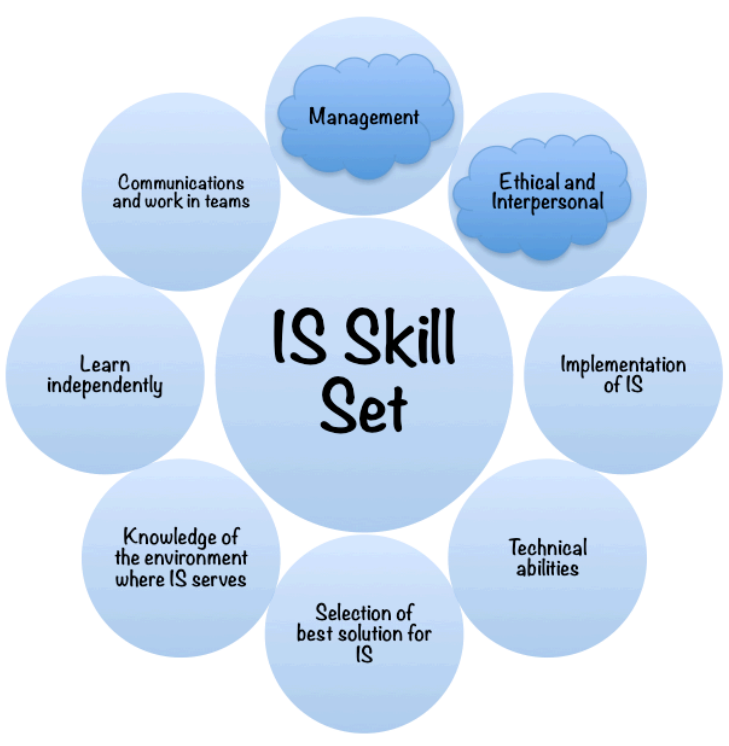

Figure 2: Skill Set of IS curricula model

The implications of these model are significant since it provides guidelines for IS curricula improvements. According to the model, IS curricula most enhance on the IS skills such as Implementation of IS, Technical skills, Selection of best solution for IS, Knowledge of the environment where IS serves, Learn independently and Communication and work in team skills. The IS skills Management and development an IS in an organization as well as Ethical and interpersonal skills are well addressed, but can always be enriched as well.

This research findings suggest the IS courses to be revised and renovated are Technological Infrastructure for Information Systems, Applications Programming, Physical Design and Systems Implementation Using Emerging Tools, Design and Implementation of Electronic Business, Decision Support Systems, Physical Design and Systems Implementation Using Database Management Systems (DBMS), Local Area Data Communication Networks, Wide Area Data Communication Networks, Project Management and Administrative Aspects of IS, Seminar on Legal Aspects of Information Systems, and Control and Security of Information Systems.

\section{LIMITATIONS OF THE STUDY}

Alumni are very good to assess the IS curriculum (Grant, Hackney, and Edgar, [5]). The identification of alumni to conduct this research was challenging since they are difficult to reach once they graduate. Alumni from 2005 to 2011 were invited to participate in both studies (2011 and 2013), which may have led to duplicity in respondent. Another limitation was the drop in participation, from $31 \%$, in the 2011 study to $13 \%$ in the 2013 study, even though 18 more invitations were sent for the 2013 study. It is advised to do generalizations from this research with caution.

\section{CONCLUSIONS}

IS curricula must be constantly evolving, to the demands of a changing business environment, to better prepare its alumni. Effective methods to measure how well the IS curriculum program's objectives are being met are important to identify which improvements needs to be adopted (Koohang, et al. [6]). In that respect, this article presented a well-elaborated method to assess the program's objectives, which can be used to improve the IS curriculum. The Skill Set of IS curricula model presented in Figure 2 shows which skills need to be refined. Academics must react to the model to opportunely keep IS curricula relevant and address the new challenges IS professionals are facing. The 


\section{Issues in Information Systems \\ Volume 15, Issue II, pp. 89-97, 2014}

model guides academia in this process. The skills to be redefined are Implementation of IS, Technical skills, Selection of best solution for IS, Knowledge of the environment where IS serves, Learn independently and Communication and work in team skills.

Future studies can be focused on how institutions assure their respective IS curriculum program's objectives are met. For example, Koohang, et al. [6] suggested to do assessment of the objectives by administrating surveys to nonsenior students and alumni every three years, as well as to senior students every semester. Another interesting future topic, as Amadi, \& Born [3] mentioned, could be on listing the best practices for IS curricula changes and implementations.

\section{REFERENCES}

1. Aasheim, C., Shropshire, J., Lixin, L., \& Kadlec, C. (2012). Knowledge and Skill Requirements for Entry-Level IT Workers: A Longitudinal Study. Journal Of Information Systems Education, 23(2), 193-204.

2. ABET (2013). Criteria for accrediting computer programs: Effective for evaluations during the 20142015 accreditation cycle, Computing Accreditation Commission. Baltimore: ABET, Inc. Retrieved May 7, 2014 from

http://abet.org/uploadedFiles/Accreditation/Accreditation_Process/Accreditation_Documents/Current/C0 01\%2014-15\%20CAC\%20Criteria\%2010-26-13.pdf

3. Amadi, E. U., \& Born, A. (2013). Information systems program and business needs: Case study of a Midwestern University. Research In Business \& Economics Journal, 7136-156.

4. Gliem, J. A., Gliem, R. R. (2003). Calculating, Interpreting, and Reporting Cronbach's Alpha Reliability Coefficient for Likert-Type Scales. 2003 Midwest Research to Practice Conference in Adult, Continuing, and Community Education, October 8-10, 2003. Columbus, $\mathrm{OH}$.

5. Grant, K., Hackney, R., \& Edgar, D. (2010). Informing UK Information Managemement pedagogic practice: The nature of contemporary higher education culture. International Journal of Information Management, 30(2010), 152-161.

6. Koohang, A., Riley, L., Smith, T. \& Floyd, K. (2010). Design of an information technology undergraduate program to produce IT versatilists. Journal of Information Technology Education, 9, 99-113. Retrieved from http://www.jite.org/documents/Vol9/JITEv9p099-113Koohang796.pdf

7. Outlay, C.N., \& Krishnan, P. (2010). Skill gaps and careers in IS compliance: Implications for IS degree programs in the US. $A C M, 130-135$.

8. Ramos-Torres, A. (2008). Proposal for the computer information systems major redesign. Certification number 101 from the Academic Senate, University of Puerto Rico Río Piedras Campus, May 27, 2008. [An Official University Document], 7-10.

9. Reichgelt, H., \& Yaverbaum, G. (2007). Accountability and accreditation: Putting information systems accreditation into perspective. Communications of the Association for Information Systems, 20(2007), 416-428.

10. Thatcher, J., Dinger, M., \& George, J. F. (2012). Information Technology Worker Recruitment: An Empirical Examination of Entry-Level IT Job Seekers' Labor Market. Communications Of The Association For Information Systems, 311-34.

11. Topi, H., Valacich, J. S., Wright, R. T., Kaiser, K., Nunamaker Jr, J. F., Sipior, J. C., \& De Vreeda, G.-J. (2010). IS 2010: Curriculum Guidelines for Undergraduate Degree Programs in Information Systems. Communications of AIS 2010(26), 359-428.

12. UCLA Academic Technology Services (2014). What does Cronbach's alpha mean? UCLA: Statistical Consulting Group. Retrieved on http://www.ats.ucla.edu/stat/spss/faq/alpha.html (July 1, 2014). 